\title{
THE ISLES (INTERNATIONAL STUDENTS' LEARNING EXPERIENCES): THE HUMAN TOUCH
}

\author{
Noor Saazai Mat Saad ${ }^{1}$, Ahmed Hani Naif ${ }^{2}$, Harison@Hanisa ${ }^{3}$ \\ 1Dr., Universiti Sains Islam Malaysia, noorsaazai@usim.edu.my \\ ${ }^{2}$ Phd Student., Universiti Sains Islam Malaysia, farookhani7@gmail.com \\ ${ }^{3}$ Assoc. Prof. Dr., Universiti Sains Islam Malaysia, harison@usim.edu.my
}

\begin{abstract}
The number of international students is increasing in higher institutions in Malaysia as the country is moving towards becoming the hub of education in the Asian Region. In the hype of welcoming and getting them enrolled in the institutions, are the host institutions ready for them? There are many aspects that can ensure the smoothness of the education journey of the international students here. A study on the elements that assist and hinder the learning experiences of the international students in a public university was embarked on. However, this paper delineates only one part of the study - the human touch. It deliberates on the people who have played a role in assisting and also hindering the international students' learning experiences. A google form consisting of 5 open-ended questions was emailed to 600 international students who were considered active in 2016 but only 40 students responded. The data were analysed qualitatively where themes on who and how the people in the host institutions were involved in assisting and also hindering the international students in moving towards completing their studies. The data revealed that the international students admitted that they found the people, namely the supervisors in the host institution to be really instrumental in their learning experiences. They named the administrative staff to be leaving quite a bad impact in their journey as international students here.
\end{abstract}

Keywords: human touch, international students, learning experiences

\section{INTRODUCTION}

In the move towards becoming the hub of education in the Asian Region, Malaysia has been welcoming in getting international students to enrol in the public as well as private educational institutions here in the country. We are fast embracing the role of the host for these sojourners. However, are we ready for them? Are we as ready as the traditional hosts like The United Kingdom, The United States and Australia in welcoming and providing the world best education for the international students? A study has been done to look into the elements that assist and hinder the success of international students' learning experiences. This paper delineates only one part of the study - the human touch. 
This paper begins with a discussion on the two main players involved in the process of internationalisation of education. They are the students who have crossed the geographical border to study in a university in a foreign land; they are termed as international students (ISs) and the management - the host country and the academics. The discussion looks into the different perceptions and experiences; positive and negative, problems, issues and steps taken by these parties to ensure the success in executing the internationalisation of higher education. It then moves into the study and the theory that underpins the study.

\section{THE PLAYERS}

In internationalising higher education; two main parties are directly involved. They are the IS, the management and the academic community of the institution. The discussion centres on the literature of their perceptions on being involved directly in the implementation of international higher education. How the richness of diversity as discussed above can be experienced and cherished; and paradoxically can cause so much anxiety and discomfort. What are the assumptions that one has of the other that might tarnish the relationships. And having global and universal personality, how one can create a more tolerable and conducive environment to uphold the definition by Knight (1999) in order to foster teaching, learning and good connection.

\subsection{Player 1: The International Students (ISs)}

Coming from a far-off land in pursuit of education, ISs are filled with hope and anticipation. Yet they are gripped with fear and anxiety. A new place would usually mean a different place from the homeland with different weather, language, food, culture, custom, system, people and the list goes on. Their dissimilarities in the way of life and everything else in the new country warrant the name "The Other" as evidence in Doherty and Singh (2005), Hellmundt and Fox, as cited in Trahar (2008) and Trevaskes et al. (2003). And due to their differences, they have become interesting subjects to be studied - whether to highlight the various distinctions, to discuss their problems or to research on their communicative strategies in coping with the new environment; the aim is to help them to survive and give an insight to the other players like the lecturers and the management team members to understand and even assist them in making their stay and education in the host country worthwhile and meaningful.

It has been established that international students (ISs) are the students who sojourn in another country in order to pursue their education. Ryan and Caroll (2005) define ISs as the students who are residing in a foreign country for tertiary study. This part of the literature review will discuss the main issue that is essential to the emergence of international students. The literature is taken from major players like UK, US and Australia (with a big focus on Australia as it is the nearest to Malaysia) as they are the pioneers in the field of ISs. It is then followed by the presentation of the scenario in Malaysia.

In realising the internationalisation of education, there are many aspects that need to be taken into consideration. However, this study focuses on the international students (ISs), the people who are involved in the "real process of internationalisation" (Knight 2004:1). Their dissimilarities in the way of life and everything else have become interesting subjects to be studied - whether to highlight the various distinctions (Learning styles - Wong 2004; interpretations of academic writing - Arkoudis \& Tran 2007), to discuss their problems (adjustments - Andrade 2006; Fritz et al. 2008; Jiang et al. 2009; language difficulties - Sawir 2005) or experiences (Myles \& Cheng 2003; overall - Novera 2004; interaction with lecturers - Guilfoyle \& Harryba 2009). It can be deduced that the literature can be categorised in two broad areas - social and academic.

Some overseas studies overlook the importance of origin of the international students. Studies by Andrade (2006), Fritz et al. (2008), Hellsten and Prescott (2004), Hunley (2009), Myles \& Cheng (2003), Tavakoli et al. (2009), and Sakurai et al. (2009) have grouped all international students together. Nevertheless, some actually focus on certain nationality like Chinese ; for example, Jiang et al. (2009), Zhu et al. (2007), Sayers and Franklin (2008), and Arkoudis and Tran (2007); Indonesians (Novera 2004); Indians (Sameena Ahmed 2006); Asians in general (Sawir 2005, Wong 2004, Niles 1995, and Ramburuth \& Mc Cormick 2001); Seychelles (Guilfoyle \& Harryba 2009); Turks (Bektas et al. 2009) and Iranians (Mehdizadeh \& Scott 2005). Whatever the reason for the research, the aim is to better understand them and give an insight to the other stakeholders like the academics and the host university management team members to assist them in making their stay and education in the host country worthwhile and meaningful.

In 2011, Australia, the US and the UK were the hosts for 557 425; 723277 and 428225 ISs, respectively. The numbers are retrieved from their government websites. However, their history of hosting ISs goes back decades ago. Australia, for instance, has been a part of international education since the Colombo Plan in 1950 (Cuthbert et al. 2008; Dawson \& Hacket 2006). Malaysia on the other hand, only began intensively in the new millennium, thus literature on ISs is very much lacking. 
Table below shows the recent articles that highlight issues about ISs' academic problem in Malaysia.

Table 1: Recent studies on ISs in Malaysia

\begin{tabular}{|c|c|c|c|c|}
\hline Author/s & Focus/Issue & Sample & Methods & Findings \\
\hline $\begin{array}{l}\text { Zuria et al } \\
2010\end{array}$ & Acculturation & $\begin{array}{l}30 \text { ISs from } \\
3 \\
\text { universities. }\end{array}$ & $\begin{array}{l}\text { Focus group } \\
\text { interviews (5-6 } \\
\text { in each group) }\end{array}$ & $\begin{array}{l}\text {-Malaysians do not speak English } \\
\text {-Malaysians speak English with Malay } \\
\text { accent } \\
\text {-Lack of English usage on signage } \\
\text { and documents } \\
\text {-Three big problems: Climate, Culture } \\
\text { and Care }\end{array}$ \\
\hline $\begin{array}{l}\text { Khairi \& } \\
\text { Rechards } \\
\text { (2010) }\end{array}$ & $\begin{array}{l}\text { Perception of } \\
\text { Arab } \\
\text { postgraduates }\end{array}$ & $\begin{array}{l}326 \text { Arab } \\
\text { respondents } \\
\text { from } 5 \\
\text { universities }\end{array}$ & $\begin{array}{l}\text { Questionnaire } \\
-3 \text { parts: } \\
\text { English } \\
\text { Proficiency, } \\
\text { Cultural \& } \\
\text { Academic } \\
\text { Barriers } \\
\end{array}$ & $\begin{array}{l}\text {-Language class is poor for all. } \\
\text {-Academic challenges cause worries } \\
\text { Thus, students must be linked better } \\
\text { to academic research and writing }\end{array}$ \\
\hline $\begin{array}{l}\text { Alavi \& Syed } \\
\text { Mohamed } \\
\text { (2011) }\end{array}$ & IS problems & $\begin{array}{l}135 \text { IS from } \\
3 \text { countries } \\
\text { (117-Iran, } \\
\text { 10-Saudi \& } \\
\text { 8-China) } \\
57 \text { males, } \\
78 \text { females }\end{array}$ & $\begin{array}{l}\text { Mixed } \\
\text { methods - } \\
\text { Questionnaire } \\
\text { \& Interview } \\
\text { with } 3 \text { student } \\
\text { presidents } \\
\text { from countries } \\
\text { involved (Iran, } \\
\text { Saudi \& } \\
\text { China) }\end{array}$ & $\begin{array}{l}\text {-Five (5) most disturbing 'problem' } \\
\text { categories : } \\
\text { 1) Social \& recreational } \\
\text { 2) Curriculum \& Method of teaching } \\
\text { 3) Adapting to future career } \\
\text { 4) Financial, lifestyle \& career related } \\
\text { 5) Adapting to academic work }\end{array}$ \\
\hline $\begin{array}{l}\text { Manjula \& } \\
\text { Slethaug } \\
\text { (2011) }\end{array}$ & $\begin{array}{l}\text { Improving } \\
\text { learning } \\
\text { experience }\end{array}$ & $\begin{array}{l}78 \text { IS in a } \\
\text { tertiary } \\
\text { institution } \\
\text { from } 17 \\
\text { countries }\end{array}$ & $\begin{array}{l}\text { ACE } \\
\text { Questionnaire } \\
\text { by Slethaug }\end{array}$ & $\begin{array}{l}\text {-Challenges for IS: } \\
\text { 1) Differences in cultural } \\
\text { communication } \\
\text { 2) English Language Usage } \\
\text { 3) Critical thinking skills } \\
\text { 4) Technology skills } \\
\text { 5) Participation in collaborative } \\
\text { learning } \\
\text { 6) Expectations of rote learning } \\
\text { 7) Academic literacy styles } \\
\text { 8) Assimilation in and out of the } \\
\text { classroom } \\
\text { AlM: to arouse awareness to } \\
\text { institutions in Malaysia }\end{array}$ \\
\hline $\begin{array}{l}\text { Mohd Zaki } \\
\text { (2011) }\end{array}$ & $\begin{array}{l}\text { Develop \& } \\
\text { evaluate LLS } \\
\text { module }\end{array}$ & $\begin{array}{l}40 \text { IS in } \\
\text { UKM }\end{array}$ & $\begin{array}{l}\text {-Needs } \\
\text { analysis } \\
\text {-Language } \\
\text { Strategies Use } \\
\text { Questionnaire }\end{array}$ & $\begin{array}{l}\text { Problematic skills in English : } \\
\text { 1)Speaking 2.Writing 3.Reading } \\
\text { 4.Vocab \& grammar 5.listening }\end{array}$ \\
\hline $\begin{array}{l}\text { Yusliza \& } \\
\text { Chelliah } \\
\text { (2010) }\end{array}$ & $\begin{array}{l}\text { Factors that } \\
\text { affect } \\
\text { adaptation }\end{array}$ & $\begin{array}{l}\text { A } \\
\text { conceptual } \\
\text { paper }\end{array}$ & $\begin{array}{l}\text { Literature } \\
\text { Review }\end{array}$ & $\begin{array}{ll}\text { 1. } & \text { Psychology and sociocultural } \\
\text { elements } \\
\text { 2. Demographic factors } \\
\text { 3. English proficiency } \\
\text { 4. Social support } \\
\text { 5. Personality variables }\end{array}$ \\
\hline
\end{tabular}

Table 1 above portrays the problems faced by ISs in Malaysia. They include academic, social and individual factors. It can be surmised that Malaysia is in the first phase of the internationalisation of education (Noor Saazai et al., 2012) as the extant literature revolves around the problems, not yet going into the solution as 
found in literature produced in traditional host countries.

To conclude, as the direct users of internationalisation of higher education, ISs should be prepared to go through hardships and hurdles in embracing education overseas (Liddicoat, 2003). Problems can come in the form of social, cultural, academic and sometimes economic issues (Ferman, 2003). Hence, geared with deep understanding of one's own culture, belief and mission in life; and be physically, mentally and financially ready, one can meet these challenges head on and decide on the best way to get them settled. However, most importantly is to equip oneself with the mentality that changes can sometimes be good and the ability to adapt to changes that bring positive effect on oneself, community and even country.

\subsection{Player 2: The Host Institution (Management) And Lecturers}

They are the key players in internationalising higher education as they are the agents that are responsible to realise the concept. The management team members in the host institution welcome ISs by providing suitable support, services and activities (Ferman, 2003; Knight, 1999; Liddicoat, 2003) especially during the transition period as this is the crucial time to build a strong foundation for them to survive and succeed in the subsequent academic journey (Andrade, 2006). The activities/programmes are like orientation week, buddy system (Austin et al., as cited in Hellsten, 2005), language support programmes, workshops on tertiary level educational conventions, for example, reading and writing critically, note-taking, library tour, using endnote, power point and others. There are usually follow-up and even new sessions and programmes once the transition time is over. Furthermore, there are handouts, brochures, handbooks, websites, chatrooms that can assist the newcomers in adjusting and there are even counsellors for them to meet individually and they can also have a one-to-one consultation with a tutor to help them with their assignment, mini dissertation and others. In order to make ISs experience in the university and country an unforgettable and a balance one, the management together with the student body usually organises social functions; as simple as get-together sessions during weekdays to a grand dinner at the end of an academic session. It is very important that the host institution executes all these events as Hellsten (2008) stresses that it is the host institution that has to take the initiative to develop or redevelop any process of change among the students. In this context, the university cannot control the diversity that ISs come in with, but, it can provide avenues for them to 'change' their mindset and to be more receptive to the new rules, standards, norms and values in the new place.

One dangerous assumption is where ISs are seen as students who are fully equipped with skills to do well in their studies (Trevaskes et al., 2003). As pointed out by the authors, this is also a misconception as IS might not be totally ready because they come in with different educational norms, cultural beliefs and experiences in the teaching and learning process. They first need to acclimatise themselves to the new place. Some might arrive at the adjustment stage and embrace intercultural competence fast, but some might take time. Peter suggests that the best is to talk about it, as cited in Gibson, 2008. Both players - teachers and learners need to "reimagine" and "rethink" their roles in the changing situation (p. 204). Interestingly, some assumptions have been proven wrong. For instance, Lad and Ruby, as cited in Andrade (2006) investigate a general belief that says ISs prefer the system of education in their homeland. However, $80 \%$ of the students surveyed wanted something different like direct experience, involving contact with topics and situations related to their studies rather than lecture and teacher-centred approach.

\section{THE STUDY: THE UNDERPINNING THEORY}

The study was embarked on in order to look into the elements that might have assisted or hindered the success of language learning for ISs. The main element is regarding the people around the students because as highlighted in the earlier section, the players in the internationalisation concept are the ISs and the people at the institutions. This study is underpinned by the Ecology of Human Development Theory. The cornerstone concept of the theory is the transaction between man and the environment in the man's developmental process. Studying in a foreign country leads to the development of a person in many ways and it involves the environment.

Ecology of Human Development theory is propounded and perfected by Urie Bronfenbrenner, an American psychologist. The theory was first published in 1970s (Bronfenbrenner, 1994) but has undergone expansion. Bronfenbrenner started with 4 types of the environments - micro-, meso-, exo, and macrosystems, and later added chronosystem. He posits that there are different types of environmental systems that influence human development and they are all related like 'Russian dolls' - where "the ecological environment is conceived as a set of nested structures, each inside the other like a set of Russian dolls. Moving from the innermost level to the outside" (Bronfenbrenner, 1994, p.39). In other words, the microsystem is in the most inner circle, then it moves outwards with the mesosystem, followed by the exosystem and then the macrosystem. This is elucidated vividly by diagram 1 below. 


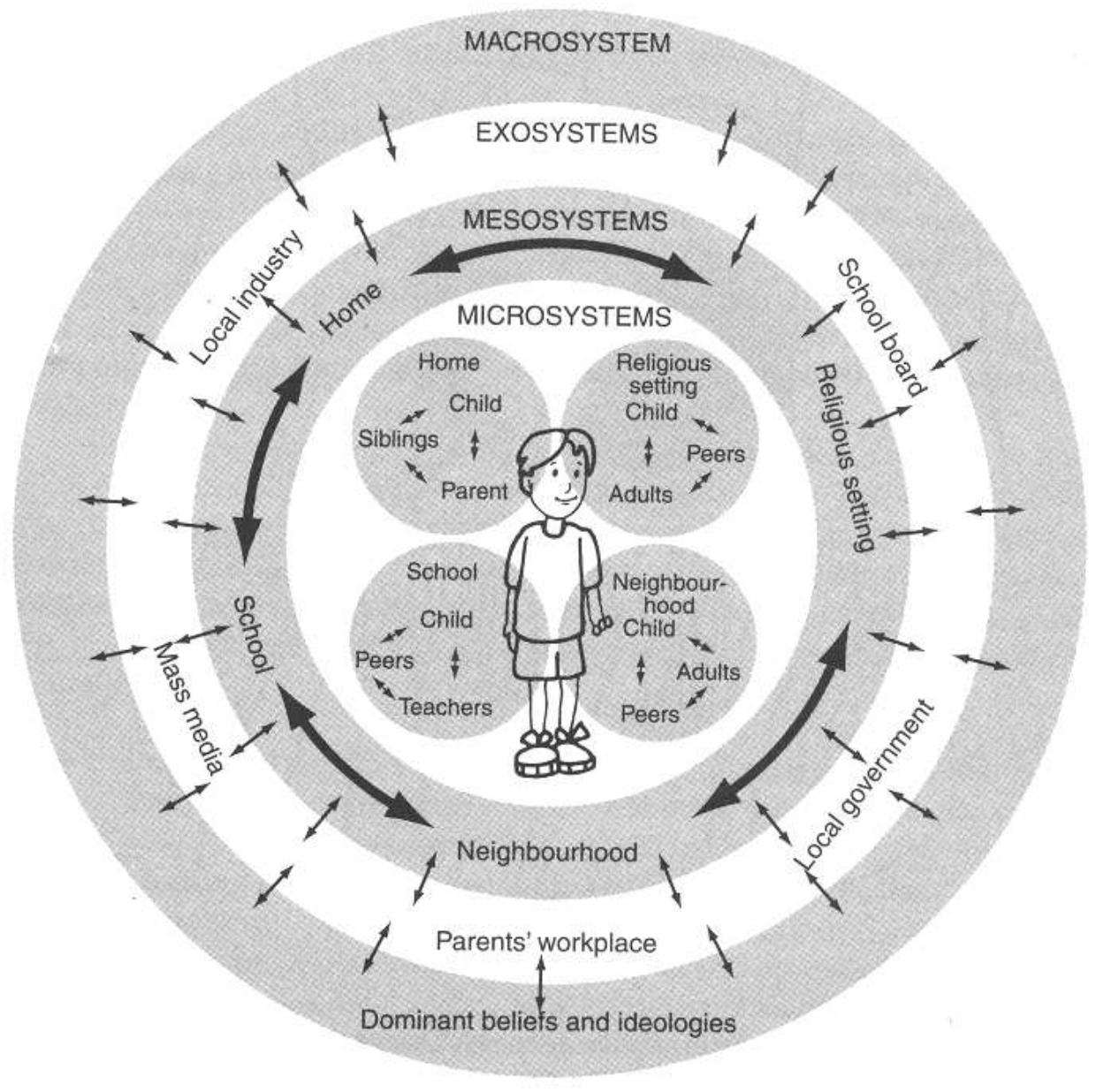

Diagram 1: Ecology of Human Development Theory. Source: Penn (2005, p.45)

Diagram 1 is the visualisation by Penn (2005) which is recommended by Harkonen (2007) as a clear representation of the Ecology of Human Development Theory. It shows the relationship of the 4 out of the 5 systems as proposed by Brofenbrenner. The fifth system - Chronosystem, is usually symbolized as a sash across the systematic overlapping circles. The arrows show that there is reciprocity in the relationships between the systems.

However, Among the 5 systems, the focus of this paper is on the first - the microsystem. As discussed, microsystem is made up of the person's immediate environment like his/her family, school, workplace and others. It involves "a pattern of activities, roles and interpersonal relations experienced by developing person, a face to face setting with particular physical and material features...containing other persons with distinctive characteristics of temperament, personality and systems of belief" (Harkonen, 2007). They, in return, are affected by the developing person too (Bronfenbrenner, 1977).

To encapsulate, the Ecology of Human Development Theory by Bronfrenbrenner (1977) does not only explain the social system factors that influence the development of an individual, but also how the individual's socialisation shapes the environment around him or her.

It can be surmised that Brofenbrenner's Ecology of Human Development Theory looks into development of a human being in general. A study by Tonttila (2006) has used this theory to study the development of a disabled child. In a similar vein, Kolb and Kolb (2005) have employed this theory together with two other theories to explain the Learning Space Theory, one part of their well-known Experiential Learning Theory (ELT). Similar to the Ecology of Human Development Theory, ELT also accentuates on the interactions between human and environment.

The study was conducted at a young public university in Malaysia. Most of the ISs in this university are pursuing their postgraduate studies. At the time of the study, there were only 650 active ISs. 


\section{THE STUDY: METHODOLOGY}

Most of the ISs in the university do not stay on campus. Thus, they need to be reached online. This study utilised the Google Form to ask open-ended questions to the ISs. The questions revolve around the elements that assist and hinder the positivity of international students' learning experiences. The respondents are to write short paragraphs to answer each question. Their demographic details are also collected. The Google Form was then e-mailed to the 650 e-mail addresses belonging to the active postgraduate students in 2016. The e-mail addresses were requested from Centre for Information Technology with a written permission from the Centre for Graduate Studies (CGS). The Google Form was sent three times to all the addresses - March 2016, May 2016 and August 2016. However, after the third round, there were only 40 responses.

Although the data collection for the study was done in a quantitative manner, the data collected were in 'words and expressions'. Thus, the most suitable data analysis is thematic analysis. The thematic analysis was managed by ATLAS.ti.

\subsection{Demographic Details}

Among the 40 respondents, $75 \%$ were doing Ph.D while $25 \%$ were completing their master's degree. Almost half of them were in their third and fourth semester. Others were already in the seventh semester and above. As for the fields of study, $62.5 \%$ were doing pure sciences while $37.5 \%$ were in the social science fields. These 40 respondents came from 25 different countries with around 2 to 5 respondents from Bangladesh, Libya, Nigeria, Indonesia, Oman and Yemen. In the span of 6 months, $45 \%$ of them admitted that they are on campus only 1 to 2 months. Further, only $37.5 \%$ of the students have their family members with them here, and about $62.5 \%$ of them stay alone or with their friends. Most stay in homestays, hotels and apartments.

\subsection{Findings and Discussion}

This section is presented according to the research question and the discussion is done alongside. In tandem with the nature of the data analysis which is thematic analysis, the findings are seen in terms of themes and as evidence, extracts from the responses are included. Further, the network view, an output from ATLAS.ti for the themes for each research question is included.

\subsubsection{Research question 1: Who are the people who have been involved in the international students' learning experiences?}

The data from the 40 respondents show that there are people who have contributed positively and also negatively to their learning experiences. As for the former, the data reveal that there are 4 groups of people who have been positively involved in the learning experiences of the international students. The diagram below has the summary of the groups.

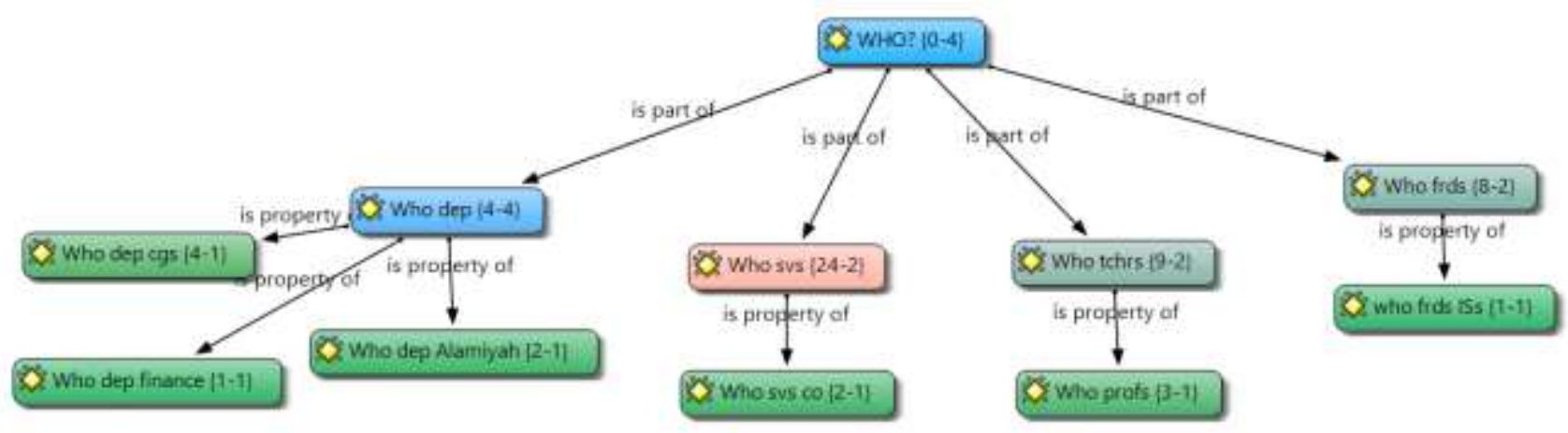

Figure 1: Network View from ATLAS.ti for Research Question 1 (positive)

From the figure above, the 4 groups of people who are involved in the international students' learning experiences are the administrators at the departments, the supervisors, the teachers/lecturers and the friends. In terms of frequency, it can be seen that the highest number of reported cases is the supervisors (26 reports), and then the teachers/lecturers (12 reports). It is followed by the administrators (11 reports) and friends (9 reports).

In other words, most of the respondents have named the supervisors to be the people who have played a 
positive role in their learning endeavour. They have described the supervisors to be very supportive. Some of the positive adjectives associated with supervisors are:

Helpful (line 9), berdedikasi [dedicated] (line 13), quite Good (line 19), cooperative (line 40), kind (line 51), supportive (line 54), experienced (line 66), helpful and responsive (line 69), kind, fatherly, and supportive (line 83), gentle, always updated (line 91), awesome (line 160), and cooperative \& friendly (line 166).

As for the international students' negative learning experience, they have named the same groups of people but the frequency differs greatly. The people involved and the number of frequency can be seen in the figure below.

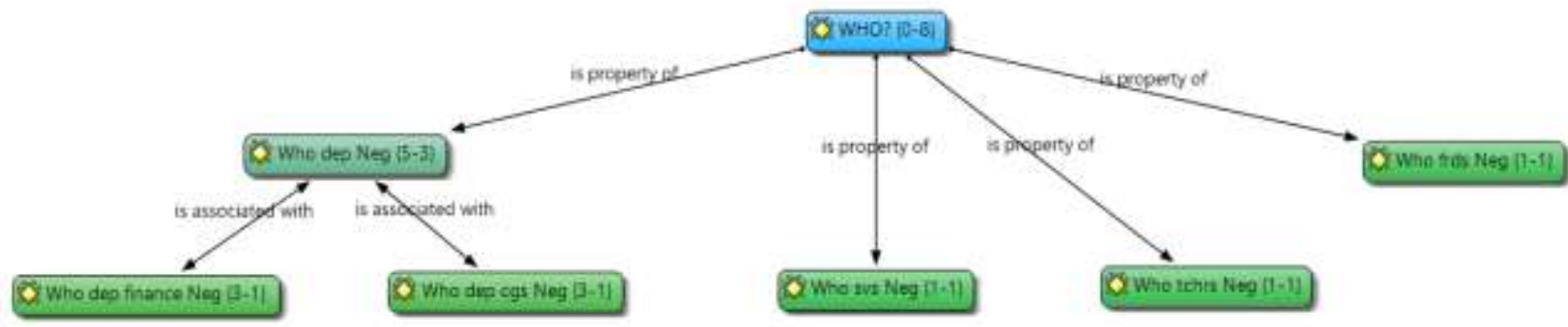

Figure 2: Network View from ATLAS.ti for Research Question 1 (negative)

Figure 2 above shows the people involved negatively in the learning experiences of the international students. The highest number of complaints is made about the people in the department or administrators (11 reports). While for the supervisors, teachers and friends, each group is reported only once. They are described negatively as below:

not functioning smoothly (line 44), slow (line 65), not friendly (lines 82,108 \& 139), not professional (line 143), very lazy (line 144), don't care (line 143), and don't follow the rules (line 143).

The international students explicitly named the departments where the administrators were considered as not supporting their learning endeavour. The departments listed are the Centre for Post Graduate Studies, Finance Department and own faculty department/office. Almost all of the above descriptions are used to describe the administrators in the named departments.

Although the international students named the same 4 groups of people to be involved in both the positive and negative learning experiences, due to the big number of difference in the frequency and also the long list of positive adjectives given, it can be surmised that supervisors are the most important people in the international students' learning experiences. There are 24 reports favouring the supervisors, while there is only 1 report which says otherwise.

\subsubsection{Research question 2: How are the learning experiences positive and negative?}

The preceding section discusses Research Question 1 which is regarding the groups of people who have positively and negatively involved in the international students' learning experiences (ISLEs). The findings for research question 2 will further detail the ways in which the people have assisted or hampered the ISLEs. The presentation of the findings begins with the themes of how people have assisted the ISLEs, and it is followed by the elucidation of the themes via the extracts from the respondents' answers. This is also done for the people who have hampered the ISLEs.

The data reveal that there are two ways in which the people in the host institution have assisted the ISLEs. Figure 3 below has the themes which emerge from the data collected via Google form. 


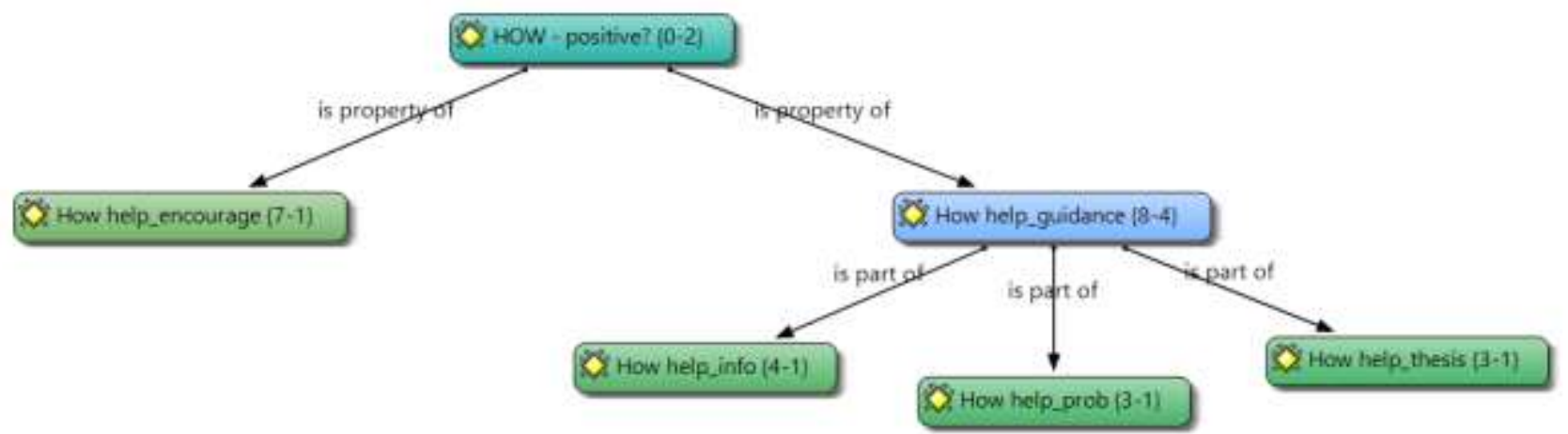

Figure 3: Network view from ATLAS.ti on Research Question 2 (Positive).

Figure 3 displays two main themes and three subthemes under one main theme. The main themes are encouragement and guidance. In other words, the respondents expressed how the people, especially the supervisors have helped them in their learning experiences by encouraging and guiding them to complete their studies. Guidance is seen in terms of how the supervisors have helped them by giving important information, solving problems, and assisting them in their thesis completion. Below are the extracts taken to show how the supervisors have assisted the students:

Extract 1 (lines 128:129)

has made me a better person personally. It motivates me to explore and dig more knowledge as I experienced a competitive surrounding.

Extract 2 (line 145)

provide me proper guidelines to complete my tasks.

Extract 3 (lines 12-16)

Supervisor saya ... banyak memberikan tunjuk ajar dan nasihat. begitu juga ... supervisor sy sewaktu MA dahulu, TERLALU berdedikasi dlm menyemak tulisan saya, setiap muka surat dan perkataan akan beliau baca dan semak kemudian mengemukakan komen dan nasihat serta menunjukkan kpd beberapa reference yg amat membantu dlm melengkapi thesis sya. termasuk cara menulis, menyusun boleh kata $\mathrm{dlm}$ semua aspek research sy beliau sangat membimbing. kedua-dua supervisor saya...

[My supervisor has given me a lot of guidance and advice. Same goes to my supervisor when I was doing my Master's, VERY dedicated in checking my work, my supervisor read and checked every page and every word, and then gave comments and advice, also showed very helpful references to complete my thesis. Both my supervisors guided me on how to write and arrange everything in my research]

Extracts 2 and 3 show that the supervisors have assisted the students in terms of the latter completing their tasks and thesis. As for extract 1, it is an evidence of how a supervisor has encouraged the student to become a better person.

The finding above is a portrayal of positive experiences of the international students' learning. Next part shows how the administrators at the institution are involved in making the international students' learning experiences to be negative. Figure 4 below has the themes and subthemes for the negative experiences.

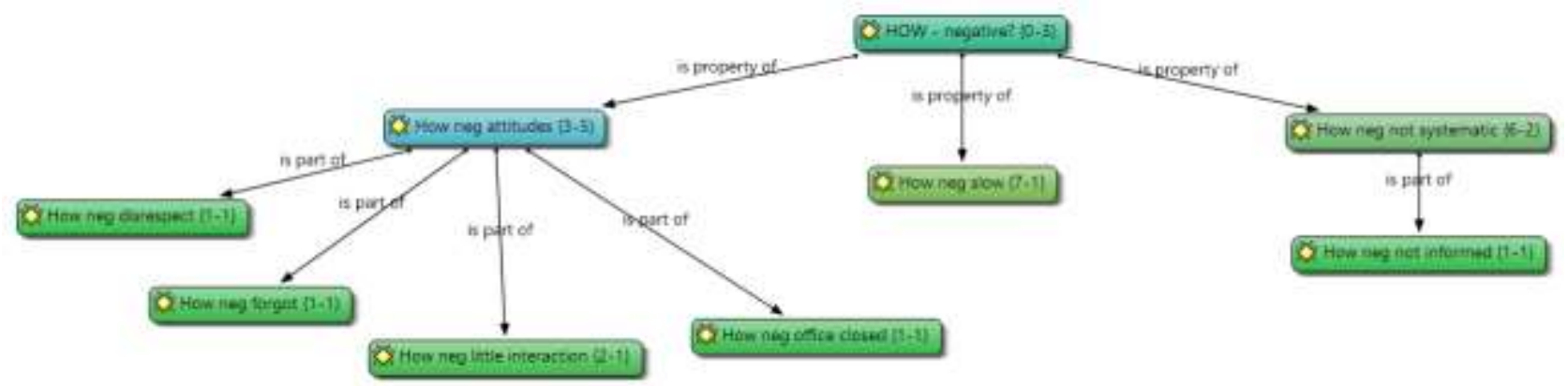

Figure 4: Network view from ATLAS.ti on Research Question 2 (Negative).

The figure above further details how the administrators at offices have made their learning experiences in 
the institutions negative. There are three themes emerging from the data, the negative attitudes, the slowness and the lack of organisation in doing their work. There are a few subthemes under the negative attitudes. The international students felt that the administrators do not really respect them and they only had little interaction with the students. Furthermore, the international students felt that the administrators were very unsystematic and the effect was that they were not informed of some important aspects. The extracts below further elucidate the negative experiences they faced:

Extract 4 (lines 105-107)

she canceled my proposal defense / qualifying test (QT) $\mathbf{3 0}$ minutes before it was started. At that time, I flew from my country for QT only. I complained but the staff said there were no examiners. I insisted to have my QT on that day, and it was done. And the surprising fact was that the examiners were there.

Extract 5 (lines 16-17)

ketika PhD form viva saya "misplace" kena buat yg baru tapi supervisor dah berangkat ke Morocco kena tunggu berapa minggu untuk hubungi beliau.

[when they misplaced my viva form, I had to fill in a new one but my supervisor had flown to Morocco and I had to wait for weeks to contact him/her]

Extract 6 (lines 44-46)

only one officer deals the student affairs. In several time, I see in CGS office, the students gather and wait and wait. The students are compelled to waste their valuable time in CGS. On the other hand, Finance division provides some wrong information. To make it correct, the students have to suffer and it takes long time to be correct.

Extracts 4-6 suggest the incompetency of the staff in charge of the matters regarding international students. This has caused the ISs to lose valuable time, and possibly money too. Feedback such as this from ISs can tarnish the name of the institution. This might deter the other ISs to enrol in the institution.

\section{CONCLUSION}

Tapping on the theory of Ecology of Human Development that is the underpinning theory of the study, it can be seen that the people who are in the microsystem (the first circle nearest to the person) are not the family members, instead the supervisors and the administration staff play a big role in the development of ISs as academics. This is due to the nature of the situation that the ISs are in where they usually do not have their family members with them when they are studying overseas. This is evident in the low percentage of students staying with their family members while pursuing their studies in Malaysia. Thus, the microsystem of a person differs according to the situations the person is undergoing.

The positive experiences of the ISs with their supervisors suggest the readiness of the supervisors at the institution to be important players in the internationalisation of higher education. In other words, they might have been ready to reimagine and rethink of their roles in dealing with ISs. Furthermore, the supervisors themselves might have studied overseas, thus, that valuable experience might have equipped them with the necessary mindset to interact with the ISs successfully. As for the negative experiences that ISs went through with the administration staff, it might have been due to the different cultures and norms as the administration staff might have had no interaction with any foreigner before. Since the institution is young and new, that might have been the case. Therefore, with experience, it is hoped that the administration staff are more open and accepting to the ISs.

\section{ACKNOWLEDGEMENTS}

This research was financially funded by USIM's (Universiti Sains Islam Malaysia) Incentive Grant.

\section{REFERENCE LIST}

Alavi, M., \& Mansor, S. M. S. (2011). Categories of Problems among International Students in Universiti Teknologi Malaysia. Procedia- Social and Behavioral Sciences, 30, 1581-1587. doi: 10.1016/j.sbspro.2011.10.307

Andrade, M. S. (2006). International students in English-speaking universities: Adjustment factors. Journal of Research in International Education, 5 (2), 131-154. 
Arkoudis, S., \& Tran, L.T. (2007). International students in Australia: Read ten thousand volumes of books and walk ten thousand miles. Asia Pacific Journal of Education, 27(2), 157-169.

Bektas, Y., Demir, A., \& Bowden, R. (2009). Psychological adaptation of Turkish students at U.S. campuses. International Journal of Advanced Counselling, 31,130-143.

Bronfenbrenner, U. (1994). Ecological models of human development. International Encyclopedia of Education, Vol. 3, 2nd. Ed. Oxford: Elsevier.

Bronfenbrenner, U. (1977). Toward an Experimental Ecology of Human Development. American Psychologist. July, 513 - 531

Cuthbert, D., Smith, W., \& Boey, J. (2008). What do we really know about the outcomes of Australian international education? A critical review and prospectus for future research. Journal of Studies in International Education, 12, 255-275.

Dawson, J., \& Hacket, J. (2006). Developing service quality for international students. Paper presented at the Australian International Conference 2006. Retrieved February 15, 2010, from www.idp.com/aiec

Doherty, C. \& Singh, P. (2005). How the West is done: Simulating Western pedagogy in a curriculum for Asian international students. In P. Ninnes \& M. Hellsten (Eds.), Internationalizing higher education : Critical explorations of pedagogy and policy (pp. 53- 74), Hong Kong : Comparative Education Research Centre.

Ferman, T. (2003). Ways forward in developing the writing skills of international students. In A.J. Liddicoat, S. Eisenchlas \& S. Trevaskes (Eds.), Australian perspectives on internationalising education (pp. 3952), Melbourne: Language Australia.

Fritz, M.V., Chin, D., \& DeMarinis, V. (2008). Stressors, anxiety, acculturation and adjustment among international and North American students. International Journal of Intercultural relations, 32, 244-259.

Guilfoyle, A.M., \& Harryba, S. (2009). Understanding Seychelles international students' social and cultural experiences during transition to an Australian university. The International Journal of Learning, 16(11), $1-22$.

Harkonen, U. (2007). The Bronfenbrenner ecological systems theory of human development. Scientific articles of V International Conference PERSON.COLOR.NATURE. MUSIC. October 17-21, 2007. Daugavpils University, Saule. Latvia.

Hellsten, M. (2008). Researching international pedagogy and the forming of new academic identities. In M. Hellsten \& A. Reid (Eds.), Researching international pedagogies (pp. 83-98), Dordrecht : Springer.

Hellsten, M., \& Prescott, A. (2004). Learning at university: The international student experience. International Education Journal, 5(3), 344-351.

Hunley, H. A. (2009). Students' functioning while studying abroad: The impact of psychological distress and loneliness. International Journal of Intercultural Relations, 1-7.

Jiang, M., Green, R. J., Henley, T.B., \& Masten, W.G. (2009). Acculturation in relation to the acquisition of a second language. Journal of Multilingual and Multicultural Development, 30(6), 481-492.

Khairi, O. A.-Z., \& Rechards, C. (2010). Arab Postgraduate Students in Malaysia: Identifying and overcoming the cultural and language barriers. Arab World English Journal, 1(1), 107-129.

Knight, J. (2004). Internationalization remodeled: Definition, approaches, and rationales. Journal of Studies in International Education, 8(1), 5-31.

Knight, J. A. (1999). Internationalisation of higher education. In H.de Wit \& J.A Knight (Eds.), Quality and internationalization in higher education, (pp. 13-28), France: OECD Publications.

Kolb, A. Y., \& Kolb, D. A. (2005). Learning styles and learning spaces: Enhancing experiential learning in higher education. Academy of Management Learning and Education, 4(2), 193-212.

Liddicoat, A.J. (2003). Internationalisation as a concept in higher education: Perspectives from policy.

In A.J. Liddicoat, S. Eisenchlas \& S. Trevaskes (Eds.), Australian perspectives on internationalising education (pp. 13-26), Melbourne: Language Australia.

Manjula, J., \& Slethaug, G. (2011). The Business of Education : Improving International Student Learning Experiences in Malaysia. Paper presented at the 14th International Business Research Conference, 
Dubai UAE.

Mehzideh, N., \& Scott, G. (2005). Adjustment problems of Iranian international students in Scotland. International Education Journal, 6(4), 484-493.

Mohd Zaki M.A. 2011. Development and evaluation of a learning-to-learn English module for EFL learners. Faculty of Education, Universiti Kebangsaan Malaysia. Master.

Myles, C., \& Cheng, L. (2003). The social and cultural life of non-native English speaking international graduate students at a Canadian university. Journal of English for Academic Purposes, 2, $247-263$.

Penn, H. (2005). Understanding early childhood education. Issues and controversies. Glasgow: Bell \& Bain Ltd.

Niles, F.S. (1995). Cultural differences in learning motivation and learning strategies: A comparison of overseas and Australian students at an Australian university. International Journal of Intercultural Relations, 19(3), 369-385.

Noor Saazai, M.S., Melor M.Y, \& Mohamed Amin, E. (2012). Research on international students in traditional host countries and Malaysia: Some potential areas in Malaysia. Paper presented at the $6^{\text {th }}$ International Conference on University Teaching and Learning (InCULT) 2012, Concorde Hotel, Shah Alam, 20- 21 November 2012.

Novera, I.A. (2004). Indonesian postgraduate students studying in Australia: An examination of their academic, social and cultural experiences. International Education Journal, 5(4), 475-487.

Ramburuth, P., \& McCormick, J. (2001). Learning diversity in higher education: A comparative study of Asian international and Australian students. Higher Education, 42, 333 - 350.

Ryan, J., \& Caroll, J. (2005). 'Canaries in the coalmine': international students in Western universities. In Caroll, J., \& Ryan, J. (Eds). Teaching International Students: Improving Learning for all (pp. 3-10). NY: Routledge.

Sakurai, T., McCall-Wolf, F., \& Kashima, E.S. (2009). Building intercultural links: The impact of a multicultural intervention programme on social ties of international students in Australia. International Journal of Intercultural Relations, 1-10.

Sameena Ahmad, (2006). International student expectations: The voice of Indian students. Paper presented at the Australian International Conference 2006. Retrieved February 15, 2010, from www.idp.com/aiec

Sawir, E. (2005). Language difficulties of international students in Australia: The effects of prior learning experience. International Education Journal, 6(5), 567-580.

Sayers, J., \& Franklin, T. (2008). Culture shock! Cultural issues in a tertiary course using reflective techniques. Reflective Practice,9(1), 79-88.

Tavakoli, S., Lumley, M.A., Hijazi, A.M., Slavin-Spenny, O.M., \& Parris, G.P. (2009). Effects of assertiveness training and expressive writing on acculturative stress in international students: A randomized trial. Journal of Counseling Psychology, 56(4), 590-596.

Tonttila, T. (2006). The parenthood experience of a mother with a disabled child and the meaning of the social environment and parent - professional partnerships. University of Helskinki. Faculty of Behavioural sciences. Department of Applied Sciences of Education. Research report 272.

Trahar, S. (2008). Close encounters of the cultural kind. In M. Hellsten \& A. Reid (Eds.), Researching international pedagogies (pp. 45-64), Dordrecht: Springer.

Trevaskes, S., Eisenchlas, S. \& Liddicoat, A. J. (2003). Language, culture and literacy in the internationalization process of higher education. In A.J. Liddicoat, S. Eisenchlas \& S.

Trevaskes (Eds.), Australian perspectives on internationalising education (pp. 1-12), Melbourne: Language Australia.

Wong, J.K. (2004). Are the learning styles of Asian international students culturally or contextually based? International Education Journal, 4(4), 154-166.

Yusliza Mohd. Yusoff, \& Chelliah, S. (2010). Adjustment in international students in Malaysian public university. International Journal of Innovation, Management and Technology, 1(3), 275-278.

Zhu, C., Valcke, M., \& Schellens, T. (2007). A cross-cultural study of Chinese and Flemish university 
students: Do they differ in learning conceptions and approaches to learning? Learning and Individual Differences, 18, 120 -127.

Zuria, M., Salleh, A., Saemah, R., \& Noriah, M. I. (2010). Challenges for International Students in Malaysia: Culture, Climate and Care. Procedia - Social and Behavioral Sciences, 7, 289-293. doi: 10.1016/j.sbspro.2010.10.040 